\title{
Russell’s Bismarck: Acquaintance Theory and Historical Distance
}

\author{
Thomas Aiello \\ Department of History, Valdosta State University, Valdosta, USA \\ Email: taiello@valdosta.edu
}

Received December 21 ${ }^{\text {st }}$, 2012; revised January 23 ${ }^{\text {rd }}$, 2013; accepted February $3^{\text {rd }}$, 2013

\begin{abstract}
The role of acquaintance in Bertrand Russell's theory of descriptions is antithetical and, indeed, antagonistic toward the practice and assumptions of history. In his 1910 paper "Knowledge by Acquaintance and Knowledge by Description,” Russell attempts to reconcile direct acquaintance (or its inability to determine the personal self of others) with a descriptive knowledge that is both logical and personal. Russell tries to reconcile the internal and external worlds, attempting to explain access to impersonal knowledge inside a framework that doesn't allow acquaintance with physical objects-he distorts the historical space between researcher and subject. In so doing, he argues for the superiority of acquaintance as an arbiter of knowledge, narrowly avoiding solipsism and wrongly devaluing the most basic of historiograhpical assumptions. His conception creates false historical goals and distorts the space of historical distance, illustrated in this paper through the American slavery studies of Herbert Aptheker, Stanley Elkins, and Kenneth Stampp.
\end{abstract}

Keywords: Bismarck; Russell; Acquaintance; Description; Aptheker; Elkins; Stampp

\section{Introduction}

None can know Bismarck like Bismarck can know Bismarck. In his 1910 paper "Knowledge by Acquaintance and Knowledge by Description,” Russell attempts to reconcile direct acquaintance (or its inability to determine the personal self of others) with a descriptive knowledge that is both logical and personal. Russell tries to reconcile the internal and external worlds, attempting to explain access to impersonal knowledge inside a framework that doesn't allow acquaintance with physical objects-he distorts the historical space between researcher and subject. In so doing, he argues for the superiority of acquaintance as an arbiter of knowledge, narrowly avoiding solipsism and wrongly devaluing the most basic of historiographical assumptions. The role of acquaintance in Bertrand Russell's theory of descriptions is antithetical and, indeed, antagonistic toward the practice and assumptions of history, leaving the descriptive knowledge of historians ancillary, sitting quietly in some kind of cosmic second place. His conception creates false historical goals and distorts the space of historical distance, illustrated in this paper through the American slavery studies of Herbert Aptheker, Stanley Elkins, and Kenneth Stampp.

Russell was a public intellectual and political activist for much of his long life, but when he presented his 1910 paper before London's Aristotelian Society, his principal project remained the application of logical analysis to philosophy. Russell's Principia mathematica was at Cambridge University Press, awaiting publication ${ }^{1}$. His speeches and published papers defended an atomistic worldview against the assaults of British Idealism. The reference to Bismarck in "Knowledge by Acquaintance and Knowledge by Description” extends only through a few brief pages, but the illustration grounds the article and en-

${ }^{1}$ Russell's long life lasted from 1872-1970. Principia mathematica appeared in three volumes from 1911-1913. capsulates its argument ${ }^{2}$.

\section{Descriptions and Acquaintance}

Russell's reference to Bismarck illustrates his contention that proper names are descriptions. "The thought in the mind of a person using a proper name correctly can generally only be expressed explicitly if we replace the proper name by a description.” (Russell, 1911). He assumes for the sake of the illustration that direct acquaintance with the personal self is possible, but an outside observer attempting to know that self can only access it through description. "If a person who knew Bismarck made a judgment about him,” writes Russell, "what this person was acquainted with were certain sense-data which he connected... with Bismarck’s body.” (Russell, 1911). References to Bismarck rest on descriptions, and those descriptions rest on a direct acquaintance to some aspect of historical knowledge. Descriptions allow functional evaluations of Bismarck, getting the evaluator as close to Bismarck's direct acquaintance with himself as is possible. But "in this we are necessarily defeated, since the actual Bismarck is unknown to us.” (Russell, 1911). While each description is subjective and different, the fact of Bismarck's acquaintance with himself grounds each attempt and allows communication about him. "What enables us to communicate in spite of the varying descriptions we employ is

\footnotetext{
${ }^{2}$ The essay first appeared in print in January 1918 in the book Mysticism and Logic, an unorthodox collection of popular philosophical and more technically analytic. "Knowledge by Acquaintance and Knowledge by Description” is among the latter. Ray Monk, Bertrand Russell: The Spirit of Solitude, 1872-1921 (New York: The Free Press, 1996), 519-520. Monk’s account provides a strong biographical account of Russell's early life. For more biographical information on Russell, see Ray Monk, Bertrand Russell The Ghost of Madness, 1921-1970 (New York: The Free Press, 2000); and Ronald W. Clark, The Life of Bertrand Russell (New York: Alfred A. Knopf, 1976).
} 
that we know there is a true proposition concerning the actual Bismarck, and that, however we may vary the description (so long as the description is correct), the proposition described is still the same." (Russell, 1911). Acquaintances facilitate descriptions, and descriptions facilitate communication.

Acquaintance, for Russell, is "a direct cognitive relation" of a subject to an object- "the converse of the relation of object and subject which constitutes presentation.” (Russell, 1911). Particular sense-data and universal concepts are objects of acquaintance, physical objects and other people's minds are known by description. When a proper name is described, the description is direct. But even in this description acquaintance is necessary. Russell's logical description of a proposition such as "Bismarck is mortal" is $(\exists x)(B x \&(y)(B y \cdot y=x) \& M x)^{3}$. The value any one evaluator places on $B$ (here standing in for "Bismarck"), however, still rests on his or her acquaintance with certain facts about B. So, while description serves to supplement acquaintance with, say, Bismarck's mind, it depends on personally selected historical knowledge about Bismarckindividual acquaintance with some set of facts.

This is indirect access to Bismarck's personal entities. As described by Cora Diamond, "Bismarck, using words that he alone can understand, can reach by the straight road of acquaintance what we can get to only by side-roads, by descriptions.” (Diamond, 2000). Russell, however, clearly states that the destination we reach through "side-roads" is not equivalent to Bismarck's direct acquaintance. Though "we often intend to make our statement, not in the form involving the description, but about the actual thing described... we are necessarily defeated.” (Russell, 1911). If direct acquaintance with Bismarck's self-the relation that is the goal of description-belongs only to Bismarck, and statements about Bismarck reached by description are different than their goal (and can never get there anyway), then either the value of description is compromised or the original direct acquaintance with the self must not be the goal of that description. For Russell, getting close counts, but he never explains what that closeness gives in relation to the original goal. The proposition "which is described and is known to be true, is what interests us," he writes, "but we are not acquainted with the proposition itself, and do not know it, though we know it is true.” (Russell, 1911).

Russell's potential descriptors attempt to arrive at the knowledge Bismarck has-a perfect knowledge of the self, or something approximate to it-because he has an acquaintance with himself that others do not have. "It is," Russell argues, "very much a matter of chance which characteristics of a man's appearance will come into a friend's mind when he thinks of him; thus the description actually in the friend's mind is accidental. The essential point is that he knows that the various descriptions all apply to the same entity, in spite of not being acquainted with the entity in question.” (Russell, 1911). In 1910, there were plenty of people who could have known the living Bismarck and based their knowledge of him on direct acquaintances with the leader. Bismarck for everyone else-those in 1910 without contact and those in 2013 learning through the words of books and professors - can only be known through acquaintance with propositions, which appears farther from Bismarck's knowledge than the friend making "accidental" descriptions. But Russell notes, "We may know that the

${ }^{3}$ Generally translated: There exists an $\mathrm{x} . \mathrm{x}$ is Bismarck. [If $\mathrm{y}$ is Bismarck, then y equals x. (All instances of Bismarck are instances of $\mathrm{x}$.)] $\mathrm{x}$ is mortal. so-and-so exists when we are not acquainted with any object which we know to be the so-and-so, and even when we are not acquainted with any object which in fact is the so-and-so.” (Russell, 1911). He also describes the distance from Bismarck himself, the "various stages" of removal: "There is Bismarck to people who knew him, Bismarck to those who only know of him through history, the man in the iron mask, the longest-lived of men." (Russell, 1911). The farther we are from the self of Bismarck, the less access we have to the world of Bismarck.

\section{Acquaintance and History}

By subordinating distanced knowledge to a direct acquaintance, and by making every description dependent upon some form of personal acquaintance, Russell devalues historical knowledge. If we constantly talk past each other due to various acquaintances with proper names such as "Bismarck," how are we to reconcile statements such as this one made by historian Lothar Gall? “The Reich as created by Bismarck had not only narrowed the historical possibilities for the German nation; it had deformed the nation itself and in so doing had as it were perpetuated itself in its negative consequences.” (Gall, 1986). And how far is this statement from Bismarck himself? Does Gall's career of research on the Chancellor still fall short of the personal contact of, say, Baron von Stumm-Halberg or Wilhelm von Kardorff? Could either of them have drawn this conclusion? It bears repeating that Russell posits knowledge by description, a series of those removed acquaintances, as the only method by which one could know Bismarck. But by making that knowledge subservient to a quest for the mind of Bismarck, he sells short the independent value of that description. "Knowledge concerning what is known by description is ultimately reducible to knowledge concerning what is known by acquaintance." (Russell, 1911). This is not the verificationism of Rudolph Carnap, but it sounds like it. Russell makes all understanding dependent on acquaintance with particular sense-data, but the use of the original acquaintance in direct descriptions to represent an entity that can never be known the way the descriptor intends to know it gives Russell's acquaintance theory less surety than logical positivism. He tells us that we can know, and how to know, but he never tells us what we can know-the value of a knowledge filtered through acquaintances and descriptions in relation to the self-acquaintance of our actual subject. Portraying that knowledge as "good enough" does not seem to be good enough.

Referring to Bismarck's reference to himself, Russell notes, "Here the proper name has the direct use which it always wishes to have, as simply standing for a certain object, and not for a description of the object. But if a person who knew Bismarck made a judgment about him, the case is different." (Russell, 1911). Herein lies another inconsistency. Any proposition posited by a distanced evaluator contains only a proper name, and the proper name is a representative of a collection of facts with which the evaluator is directly acquainted. Bismarck the historical actor is not in the impersonal proposition. "Historical actor" itself is simply a possible element to be directly described by the proper name "Bismarck.” In other words, each reference to Bismarck in the proposition is an opportunity for potential acquaintances. How can Bismarck's acquaintance with the self be held as the goal of descriptive propositions if such an entity as a self-acquainting Bismarck no longer exists and cannot even be found in language? Russell might respond that 
since the bases of every description are direct acquaintances, which lend access to knowledge of the world, and since (in this example) people can have direct acquaintance with the self, then both Bismarck and his self-acquaintance are justly assumed. After all, the theory of descriptions was intended as a method of giving individuals access to knowledge of the world not based on direct experience. But Russell's response would be insufficient, as any direct acquaintance that acts as an element of the direct description "Bismarck"-such as, to use one of Russell's examples, "Bismarck was the first Chancellor of the German Empire"-finds the proper name embedded in the proposition. (Russell, 1911). We are left farther and farther from the knowledge of the intended target with each new proposition attempting to posit that knowledge. No history book, for example, could possibly render a presentation of the first Chancellor of the German Empire without including a proper name. "We can only be assured," he argues, "of the truth of our judgment in virtue of something with which we are acquainted-usually a testimony heard or read.” (Russell, 1911). Even if it is taken for granted that the history book's Bismarck is equivalent to the dinner conversation's Bismarck (which perhaps is allowing too much, anyway), it remains a proper name, a stand in for another conglomeration of direct acquaintances, all of which will hinge on the inclusion of the referent's proper name.

\section{Solipsism and Knowledge}

For Russell, the theory of descriptions circumvented possible charges of solipsism in acquaintance theory by granting access to knowledge of the outside world. As Cora Diamond paraphrases Russell's arguments in "Knowledge by Acquaintance and Knowledge by Description” and other works of the early 1910s, "the limits of the world, about which I can have knowledge, and the objects in which I can denote (whether directly or in some cases only indirectly), lie outside the limits of the realm of my own experience." (Diamond, 2000). But Russell ties everything that can be known to a series of acquaintances, wholly within "the realm of my own experience." Prior to his Bismarck illustration, but in the same paper, Russell notes that physical objects and other people's minds are not "among the objects with which we are acquainted.” (Russell, 1911). If our knowledge is dependent on acquaintance with sense data (only cognized at the point in which it comes into contact with our senses, within the realm of personal experience), and that sense data is in aid of grasping truths (such as Bismarck's self awareness) that we can never know, how valid is the knowledge that lies between these two poles? It seems that Russell is masking solipsism, rather than arguing against it. If that knowledge is "indirect," can it be considered whole? Or, perhaps, can it be considered equivalent to direct knowledge that we cannot have? Russell does not answer these questions. Nor does he give a firm account of how these two forms of knowledge are cognitively related. The primacy of acquaintance makes even direct descriptions suspect, because in evaluating the logical description of, say, "Bismarck," any evaluator must have direct acquaintances for evidence of B (and those acquaintances will be unique to the evaluator, anyway). "We know that there is an object B called Bismarck," writes Russell, "and that B was an astute diplomatist. We can thus describe the proposition we should like to affirm, namely, 'B was an astute diplomatist,' where B is the object which was Bismarck.” (Russell, 1911).
Any evaluator of that description will again come to B through a unique set of acquaintances.

That uniqueness - that personalness that characterizes individual acquaintance-does not, for Russell, preclude agreed upon knowledge. "Let us assume that we think of [Bismarck] as 'the first Chancellor of the German Empire.' Here all the words are abstract except 'German.' The word 'German' will again have different meanings for different people. To some it will recall travels in Germany, to some the look of Germany on the map, and so on. But if we are to obtain a description which we know to be applicable, we shall be compelled, at some point, to bring in a reference to a particular with which we are acquainted.” (Russell, 1911). Clearly, however, Germany's shape-its border-is a valid particular, and when one participant in communication understands "German" as, "a human within the designated border of Germany," and another assumes, "descendant of the various former Saxon kingdoms," then that communication is not direct. We are constantly talking past each other. But, for Russell, the fact of Bismarck's own selfacquaintance, his existence, makes indirect knowledge-these close approximations to specific agreement—valid. Even if this state of affairs was acceptable, it does not coincide with Russell's theory of descriptions, the goal of which was clarity and specificity. Furthermore, any statement about Bismarck indirectly references Bismarck's personal knowledge, what Diamond calls his "private object." "The quantified proposition," as Diamond notes, "follows from Bismarck's private proposition.” (Diamond, 2000). This relation between a distanced description (the "quantified proposition") and Bismarck's personal knowledge demonstrates, for Russell, the benefit in the attempt. But even the interpretation of the logic of direct description rests on personal judgments about what sort of knowledge we have about an object we can never truly know (to use the aforementioned example, B), so the relation between the distanced and the personal is constantly changing.

At first glance, this emphasis on the personal can sound like psychologism, and some psycho-historical compromise between acquaintance theory and, say, traditional history or sociology, which claim to know individuals better than they know themselves, would seem appropriate. But Russell was just as disdainful of psychologism in logical formulation as was his predecessor Gottlob Frege. Frege not only sought to corral psychologism, but, like Russell, tried to define away subjectivity in knowledge. His 1892 "On Sinn and Bedeutung” describes a "common store of thoughts," which humans share "from one generation to another."4 (Frege, 1892). He would, twenty-six years later, develop his notion of thought further-its objectivity and residence in "a third realm"-explaining that it is independent of subjectivity, "timelessly true, true independently of whether anyone takes it to be true.” (Frege, 1918). Thoughts, for Frege, are the mental entities the whole has acknowledged as true, independent of what individuals think about them. What individuals think about them-ideas-act as agents of access from the mind to the outside thought. Thus, thought is objective, and ideas only serve as mediating devices to thought, never from it. Sense, too, is objective, certainly a more difficult argument to validate considering that it initially seems to stem

\footnotetext{
${ }^{4}$ Sinn translates as "sense." Bedeutung generally translates as "reference," because "reference" is the closest functional match, but bedeutung carries a linguistic weight unequalled by "reference," and so here is retained in the original German. It is also retained in editor Michael Beany's The Frege Reader, whose translation was used in this study.
} 
from the interpretation of individual minds-the places from which ideas connect to thought. "The same sense is not always connected," Frege notes, "even in the same man, with the same idea. The idea is subjective.” (Frege, 1892). This, however, only hints at what Frege expressed more clearly other places. "The sense of the name," he noted in a 1914 letter to Philip Jourdain, "is part of the thought." (Frege, 1914). If thoughts are found entities - if they are independent of mental creation, simply discovered and agreed upon by those who acknowledge axioms and laws - then the functional display of thought (perhaps not its third realm existence, but surely its useful existence in mind and discourse) is predicated on combinations of senses, which facilitate specificity in meaning. "Without a Bedeutung," Frege noted in his 1914 letter, "we could indeed have a thought, but... not a thought that could further scientific knowledge. Without a sense, we would have no thought, and hence also nothing that we could recognize as true.” (Frege, 1914).

\section{Acquaintance Theory and Its Role in Slave Histories}

Sense and Bedeutung helped Frege remove any lurking psychologism, an attempt most historians choose not to make. But psycho-historical models are fraught with difficulties of their own. Historian Kenneth Stampp elaborated an effective critique of historical psychologism and verificationism in the description of American slavery in his 1971 "Rebels and Sambos: The Search for the Negro's Personality in Slavery.” (Stampp, 1971). Like Russell and Frege, he tries to carve a middle ground that accounts for knowledge, description, and acquaintance. He criticizes the analysis of historian Herbert Aptheker, who described slaves as active participants in the culture of revolution perpetuated by slave life, as flawed for its childlike faith in the limited source material available. Aptheker's American Negro Slave Revolts claimed to have found almost two hundred fifty slave revolts and conspiracies for freedom, each including at least ten slaves. Stampp notes that while white fear and supposition of revolt mean something about slave culture, they do not necessarily mean revolt. By only countenancing written records as absolute proof (and subsequently ignoring bias, literacy rates, etc.), Aptheker skewed historical reality to create of the American slave a perpetually rebelling agent. (Stampp, 1971; Aptheker, 1943) Stampp also critiques historian Stanley Elkins's use of role theory psychoanalysis in evaluations of slave life. Elkins argued that the closed society of North American slavery and the single significance of the master/slave relationship conspired to create a childlike subservience in slaves that kept them docile and impotent, a personality he labeled "Sambo." The mistakes of his argument lie at the polar extreme from those of Aptheker. Elkins applied psychoanalytic models to an assumed group, without first evaluating the historical record to see if his various theoretical models effectively mapped on to the condition of the American slave. Stampp responds by warning of both the danger of applying psychoanalytic categories to historical groups and the contingency of comparative history without primary document research. (Stampp, 1971; Elkins, 1959). Where Aptheker practiced a tunnel-vision empiricism without a rigorous critical examination, Elkins applied critical theory to a subject he had yet to empirically evaluate. It should be acknowledged, however, that Stampp was no Russellian, and did acknowledge the validity of psychology, speech pathology, and other alternative interpretive methods in historical research ${ }^{5}$.
(Feinberg \& Kasrils, 1983) More importantly, in delineating this middle ground, Stampp never abandoned the general historical contention that proper analysis of documents and source material could lead to an understanding of slavery more complete than any slave or slavemaster could have held. Distanced knowledge was not subordinate. Propositions could render agreed upon knowledge without direct acquaintance.

For Russell, "Every proposition which we can understand must be composed wholly of constituents with which we are acquainted.” (Russell, 1911). Those acquaintances create logical propositions that stand in logical relation to other logical propositions. For Diamond, "If I can take a sentence to stand in logical relations to other sentences, then I can understand that sentence." (Diamond, 2000). So interpreters can understand sentences about Bismarck, but that understanding will still contain an element of the personal. "Considered psychologically, apart from the information we convey to others, apart from the fact about the actual Bismarck, which gives importance to our judgment," writes Russell, "the thought we really have contains the one or more particulars involved, and otherwise consists wholly of concepts.” (Russell, 1911). Those particulars, it should be remembered, are not physical objects. They are sense data, conveyed by logical propositions. In logic, however, "where we are concerned not merely with what does exist, but with whatever might or could exist or be, no reference to actual particulars is involved.” (Russell, 1911). Why is a method unconcerned with particulars used to convey particulars in aid of knowledge of the external world? If an evaluator has logic and Bismarck has self-acquaintance, why is that selfacquaintance held as the goal of inquiry? How can these be considered functionally equal? Perhaps the best counter to the problems of Russell's Bismarck was offered by Frege in 1918:

Not everything that can be the object of my acquaintance is an idea. I, as owner of ideas, am not myself an idea. Nothing now stops me from acknowledging other men to be the owners of ideas, just as I am myself. And, once given the possibility, the probability is very great, so great that it is in my opinion no longer distinguishable from certainty. Would there be a science of history otherwise? Would not all moral theory, all law, otherwise collapse? What would be left of religion? The natural sciences too could only be assessed as fables like astrology and alchemy. Thus the reflections I have set forth on the assumption that there are other men besides myself, who can make the same thing the object of their consideration, their thinking, remain in force without any essential weakening (Frege, 1918).

Russell's illustration, however, weakens. It leaves many questions unanswered as it attempts to reconcile the internal and external worlds - as he tries to have it both ways in attempting to explain access to impersonal knowledge inside a framework that doesn't allow acquaintance with physical objects. But he cannot have it both ways.

\footnotetext{
${ }^{5}$ Russell, in turn, was no Stamppian. He did, however, later in his life, provide his own evaluation on slavery, though far less nuanced than that of his historian counterparts. Speaking at the Civil Rights Freedom March, 28 August 1963, in Washington DC, Russell declared, "The treatment of the American Negro is an atrocity which has a history of three hundred years in what is now the Untied States of America... He has suffered an experience of systematic terror in which he could, and indeed can today in many parts of the Untied States, be shot down at will.” (Feinberg \& Kasrils, 1983).
} 


\section{REFERENCES}

Aptheker, H. (1943). American negro slave revolts. New York: Columbia University Press.

Diamond, C. (2000). Does Bismarck have a beetle in his box? The private language argument in the Tractatus. In A. Crary, \& R. Read (Eds.), The new wittgenstein (pp. 262-292). London: Routledge.

Elkins, S. (1959). Slavery: A problem in American institutional and intellectual life. Chicago: University of Chicago Press.

Feinberg, B., \& Kasrils, R. (1983). Bertrand Russell's America: 19451970 (Vol. 2). Boston: South End Press.

Frege, G. (1914). Letter to Jourdain. In M. Beany (Ed.), The frege reader (pp. 319-321). Oxford: Blackwell Publishing.

Frege, G. (1892). On Sinn and Bedeutung (originally published 1892). In M. Beany (Ed.), The frege reader (pp. 151-171). Oxford: Black- well Publishing.

Frege, G. (1918). Thought. In M. Beany (Ed.), The frege reader (pp. 325-345). Oxford: Blackwell Publishing.

Gall, L. (1986). Bismarck: The white revolutionary: 1871-1898 (Vol. 2). London: Allen and Unwin.

Monk, R. (1996). Bertrand Russell: The spirit of solitude, 1872-1921. New York: The Free Press.

Russell, B. (2004). Knowledge by acquaintance and knowledge by description (Originally published 1911). In Mysticism and logic. Mineola, NY: Dover Publications.

Stampp, K. (1971). Rebels and sambos: The search for the negro's personality in slavery. Journal of Southern History, 37, 367-392. doi: $10.2307 / 2206947$ 